УДК 8

DOI $10.21661 / r-473534$

\title{
Н.С. Багдарыbын
}

\section{ЭВЕНСКАЯ ГЕОГРАФИЧЕСКАЯ ЛЕКСИКА В ТОПОНИМИИ АЛЛАИХОВСКОГО УЛУСА РЕСПУБЛИКИ САХА}

Аннотация: предметом исследования является эвенский пласт в топонимии улуса. Выбрана тема географическая лексика эвенского происхождения. Работа выполнена с иелью выявления географической апеллятивной лексики эвенского языка с сравнительно-сопоставительным методом, словообразовательным, структурным, лексико-семантическим анализами. В результате выявлено семантическое соответствие апеллятивной лексики и топонимов с видами географических объектов, особенностями окружающей местности, ландшафта. Прослеживаются заимствования эвенской географической лексики в фонд индигирского говора якутского языка. Материалы исследования будут применены в составлении краткого топонимического словаря.

Ключевые слова: географическая лексика, заимствованная лексика, диалект, топонимия, эвенский язык, якутский язык.

\section{N.S. Bagdaryyn}

\section{EVEN GEOGRAPHICAL LEXIS IN THE ALLOYHOVSKY ULUS TOPONYMY OF THE REPUBLIC OF SAHA}

Abstract: the subject of the study is the even layer in the ulus toponymy. The theme of geographical vocabulary of even origin is chosen. The work is carried out in order to identify the geographical appellative vocabulary of the even language with a comparative method, word-formation, structural, lexical-semantic analysis. As a result, the semantic correspondence of appellative vocabulary and place names with the types of geographical objects, features of the surrounding area and landscape is revealed. The author traces the borrowings of even geographical vocabulary to the Fund of the indigir dialect of the Yakut language. The materials of the study will be used in the preparation of a short toponymic dictionary. 
Keywords: geographical vocabulary, borrowed vocabulary, dialect, toponymy, even language, Yakut language.

Аллаиховский улус занимает низовье реки Индигирка, одного из крупных рек северо-востока Республики Саха, впадающей в Восточно-Сибирское море Северного ледовитого океана. Общая площадь территории улуса составляет 107,3 тыс. кв. км. В нем выделяются две географические зоны: тундра и лесотундра. Больше половины территории улуса покрывает тундра. С южной части тундра переходит в лесотундру.

Топонимия северо-востока республики, в том числе Аллаиховского улуса, свидетельствует об освоении региона разноязычными племенами с древних времен. Притом не родственных: юкагиров, чукчей, эвенов, якутов, русских.

Как свидетельствуют исторические предания и рассказы информантов, просторы низовья реки Индигирки населяли юкагирские роды, в последующем эвенские роды. Ко времени прихода русских первооткрывателей эвены уже были и имели хозяйственные, семейно-брачные связи с юкагирами. Они привнесли свою самобытную кочевую культуру - культуру оленевода и охотника с использованием оленьего транспорта.

Лексика эвенского языка богата своеобразной этнокультурной особенностью. Это отражается в оленеводческой, охотничьей, бытовой, духовной группах лексики, которые описаны в монографиях, статьях эвеноведов-лингвистов [1; 7 и др.].

При освоении территории ведения хозяйственной деятельности эвены обозначили названия местностей с географической номенклатурной лексикой на основе своей языковой и культурной традиции. Проведенный сравнительно-сопоставительный анализ топонимов исследуемого улуса выявил пласт географической лексики эвенского происхождения, которая и является предметом нашего исследования.

Исследователями топонимии северо-востока Сибири отмечено, что «одной из особенностей топонимии Северо-Восточной Сибири - точная передача структуры рельефа и тончайших признаков местности. ... Этому способствовало то, 
что местные жители издавна занимались охотой и оленеводством, которые требовали от людей глубокого знания местности» [6, с. 89]. Свидетельством тому топонимия Аллаиховского улуса богата эвенскими названиями, среди которых особое место занимает географическая лексика.

Актуальность данной работы определяется не достаточной изученностью в лингвистическом аспекте географической лексики эвенского происхождения в топонимии улуса. Выявление географической лексики в составе топонима является основной целью настоящей статьи.

Впервые проведен лингвистический анализ географической лексики эвенского происхождения в топонимии Аллаиховского улуса, описаны новые сравнительные материалы, которые дают возможность восстановления исконного звучания топонима, в чем и заключается новизна настоящей статьи.

Материалом исследования служит топонимическая картотека Республики Саха, составленная Ивановым М.С.-Багдарыын Сюлбэ (далее - картотека БС). Картотека является уникальным в регионе, состоит по приблизительным расчетам около 450 тысяч карточек, охватывает все улусы и наслега республики. Источниками, из которых извлекалась эвенская географическая лексика, явились «Сравнительный словарь тунгусо-маньчжурских языков», «Русско-эвенский словарь» составленный В.И. Цинциус и Л.Д. Ришес, «Язык эвенов Якутии» В.Д. Лебедева, «Эвенско-русский словарь» составленный В.А. Роббек, М.Е. Роббек, «Тюгосирский диалект эвенского языка» М.Е. Колесовой.

Эвенская географическая лексика, зафиксированная в топонимии улуса, представляется в следующих группах - орографические, гидрографические и лексика, связанная с покровом земли и леса.

Орографическая лексика - это лексика, связанная с определением рельефа земной поверхности в положительной или отрицательной форме. 
По семантике разделили на следующие подгруппы:

1. Лексика, обозначающая положительную форму рельефа (горная местность, возвышенности, бугорки):

- иитъиэкэн «ухабы, бугры в ровных возвышениях долины» [картотека БС]. Иитъиэкэн- местность с буграми, ухабами в наслеге Бөрөлөөх. Образован от эвенского йm, ìmä «зуб; зубец» [8, с. 300] при помощи суффикса -кэн оформляющего прилагательные, обозначающие качества предмета [12, с. 722];

- кадда «горный выступ к реке» [картотека БС]. Каддикаан - гора, в наслеге Ойоотун. В т.-ма. калдис «крутой (о скате)», эв. kaдdu kaлди «обрыв» [8, с. 366]. Эв. кадди калди «обрыв», ка̄лды «обрыв; крутой (о скале)» [11, с. 135, 136]. Ороним образован при помощи эвенского уменьшительного аффикса -каан. В эвенском языке каалдичаан «передний нижний отросток рога» [3, с. 169]. Возможно, горный выступ обозначен метафорически глазами эвена-оленевода. Для сравнения: скала Калдьин в соседнем Усть-Янском улусе от эв. калдин «обрыв» $[8$, c. 366$]$;

- мыгдын «мыс», если большой мыс мыгдыlндьэ [картотека БС], где -ндя суффикс эвенского языка, который указывают на большой размер географического объекта или на большую величину предмета, по которому он назван, подчеркивая при этом важность, значительность объекта [6, с. 103]. Мыгдындьэмыс в наслеге Бөрөлөөх. Т.-ма. мэгдйн «берег», эв. мэүдин (мэвдин) «берег (скалистый), яр, обрыв, уступ; мыс, выступ» [8, с. 563]. Эв. мэгдын «мыс» [11, с. 281];

- эв. босаү «склон горы (северный)» [8, с. 97] в названии озера Аччыгый Босуома (наслег Ойоотун) с адъективным тунгусо-манчжурским аффиксом $-м a[10$, c. $97-98]$;

- эв. букчан «остров» [8, с. 104] встречается в названиях озер: Буукчаан Күөлэ (наслег Бөрөлөөх), Букчалкаан (наслег Ойоотун), Букчулкаан (наслег Быйанныыр). Букчалкаан, Букчулкаан оформлены суффиксам прилагательных со значением обладания предметом -лкаан [12, с. 722];

- эв. Һулунэ «пик, скала, вершина (горы остроконечная)», где корнем является hул- «заострить (конец)» [9, с. 123]. От һулунэ образованы названия гор 
Һульллкээн, Аранас ҮрэБин Һулынчээнэ, Кэрэмэһик Һулынгчээнэ, Һулынғындьэ

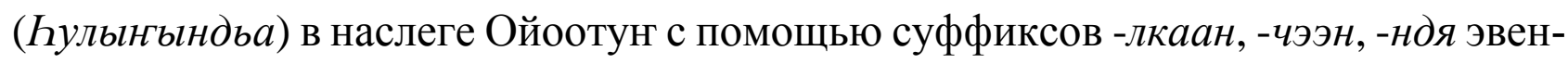
ского языка.

2. Лексика, обозначающая отрищательную форму рельефа (овраг, крутизна):

- эв. улһа Алл «овраг» [9, с. 263] в названии ручья Пронька Улһан (наслег Ойоотун) с суффиксом принадлежности 3-го лица эвенского языка -н. В картотеке Багдарыына Сюлбэ зафиксированы названия сенокосных угодий Улсаандьаа, Улсандьа в Айано-Майском районе Хабаровского края с формантами -ндя эвенского языка;

- эв. элин «склон (крутой), скат, спуск, косогор, крутизна» [9, с. 448] в названии речки Элилкээн (наслег Ойоотун) указывает в наличии крутого берега. В названии местности Maаpna Элинэ (наслег Ойоотун) эвенский элин имеет якутский аффикс принадлежности - $a$, которая свидетельствует о заимствовании.

Гидрографическая лексика - это лексика, связанная с определением водного объекта. В настоящее время апеллятив со значением «вода» эвенского языка в топонимии улуса не зафиксировано. А вода в твердом виде, характерный арктическим улусам, «лед» в эвенском языке бөһкъ. Адъектированный при помощи суффикса -лкаан бөһкълкэн, бөһкөлкэн «ледяной» [8, с. 105] лексема зафиксирован в названии местности Бускылкаан (наслег Ойоотун).

Гидрографическую лексику можно разделить по отличию состояния воды на две группы: с наличием течения и без течения. В первую группу, водный объект с течением, составляют следующие лексемы:

- эвенская биракчан «ручей» [8, с. 84] отмечен еще в первой половине XVII века в тексте рукописи участника Второй Камчатской экспедиции (1733-1743) Я. Линденау о пеших тунгусах «birakschan - ручей» [5, с. 71]. Биракчанни - Дьиут Биракчанни - ручей в наслеге Ойоотун, где -ни суффикс притяжения [11, с. 712]. Дьиут - овод (информан Е.В. Едукин) [картотека БС];

- эвенская okj̄m «река» [9, с. 9]. Гэппэнньэ Окаат (Хара Үрэх), Охаатынньа (Охоотынньа, Охоотундьа), Кьра Охоотундьа, Ухаатындьа (наслег Ойоотун) 
с выше отмеченным суффиксом -ндя, что придает значение «большая речка». Сами информанты дают объяснения на якутском языке как Улахан Үрэқиндьээ

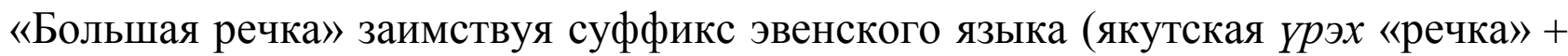
$-н д я)$

- эвенское слово на̄лдан, на̄лды «приток реки; место впадения реки, устье притока; слияние двух рек, место впадения реки в море» [11, с. 187] зафиксировано в названии речки Налдычаан в Юкагирском наслеге. -чаан уменьшительный суффикс эвенского языка [12, с. 718];

- дьупка «родник» [2, с. 29], дюпки «вдоль, в длину», «протока» [11, с. 109], дыупкы «протока2 [3, с. 164], и дьопку «озеро удлиненной овальной формы, (находящееся в долине реки), старица, заливчик» [картотека БС]. В топонимии улуса апеллятив встречается только в названиях озер наслега Ойоотун Пронька Дьопкута, Дьупку, Дьупкундьа. Семантика лексемы дьупка «родник», «вдоль, в длину», «протока» заимствовано в говор якутского языка в значении «озеро удлиненной овальной формы».

Вторую группу гидрографической лексики, связанную со стоячим водоемом, составляют апеллятивы:

- аарбутла «засохшее русло реки, озера» [11, с. 45] и аррбукун «мель, мельководье» [8, с. 49]. От аарбутла в исследуемом улусе образованы гидронимы Аарбутландьа, Аарбутлачаан (названия обмелевших озер в наслеге Ойоотун) при помощи аффикса -ндьа, -чаан. От аррбукун - название озера Аарбыкыцчаан в наслеге Бөрөлөөх.

- арбун «отлив» [8, с. 49] в лимнониме Арбын (бассейн речки Хоромой, наслег Күүрэ). Образован от эвенского глагола арбу- «мелеть» при помощи -н, который в эвенском языке является суффиксом качественного прилагательного со значением высокой способности к совершению действия [3, с. 53]. Apбын - кыра миэлкэй талахтар ҮҮнэн турар сирдэригэр, ортотугар Үөскээбит күөл «арбын - озеро, образовавшаяся по середине местности, которая занята мелкими тальниками» [картотека БС]. Еще один лимноним Apбыты в бассейне речки Дьолоон образован от арбу- «мелеть» с суффиксом эвенского языка -mbl, 
образующего от глагольных основ прилагательного внешних признаков предмета [3, с. 52].

3. Лексика, связанная с покровом земли и леса.

Эв. антық «перелесок» [8, с. 44]. В междуречье верховьев рек Болшая Эрча и Шадрин имеется гора Андыга. Ороним образован от антыл «перелесок» при помощи суффикс уменьшительности тунгусо-маньчжурских языков - $a$ [10, с. 108]. В наслеге Ойоотун имеется речка Антыгындьа характерный с некрупными лесами, сухостоем [картотека БС], который жизненно важно в арктической зоне. Лес - это огонь, огонь - это жизнь. Другой гидроним Aнтыкчан является притоком речки Шадрин бассейна реки Индигирка. Гидронимы образованы от эвенского антыц «перелесок» при помощи суффиксов -ндьа и -чаaн. Другое название местности в наслеге Ойоотун это Антьлчаан. По словам информанта: Apblbl тиит - антыл «остров из лиственниц - антыл» [картотека БС]. Топоним образован от эвенского антыль «перелесок» при помощи суффиксов -л и -чаан, где -л суффикс множественности в тунгусо-манчжурских языках $[10$, с. 25,124$]$.

Набгыкич «жидкое болото, топь», [картотека БС] от набганда̄й- «прилипнуть» [12, с. 476], набгындайи- «прилипнуть» [3, с. 176] при помощи отглагольного суффикса со значением места обычного или возможного действия [4, с. 42]. Набгыкич (Надгыкич) речка в наслеге Ойоотун. Информан Е.В. Едукин объясняет как местность, где прилипает грязь к обуви, одежде [картотека БС].

Эв. он'ин «песок, пыль; глина» [9, с. 20]. В Аллаиховском улусе оньын «земля» [картотека БС]. Оньылылдьа озеро в наслеге Ойоотун, возможно, с характерным покровом земной береговой поверхности или дна озера.

Эв. орак $\bar{\gamma} \gamma$ «заросли травы» [9, с. 24]. Орокоог озеро в наслеге Ойоотун.

В заключении: в топонимии Аллаиховского улуса выявлены около двадцати географических лексем эвенского происхождения, обозначающие орографию, гидрографию и покровы земли и леса. При сравнительно-сопоставительном анализе выявлено, что многие сохраняют исконные значения, морфологические компоненты в основах и форманты эвенского языка. Эвенские географические 
лексемы с аффиксами якутского языка свидетельствуют о достаточно тесном культурном, хозяйственном, бытовом контакте неродственных языков в исследуемой территории.

\section{Список литературы}

1. Данилова А.А. Бытовая лексика эвенского языка. - Якутск, 1991.

2. Колесова М.Е. Тюгосирский диалект эвенского языка. - Якутск: Бичик, 2006. -88 c.

3. Лебедев В.Д. Язык эвенов Якутии. - Л.: Наука, 1978. - 208 с.

4. Леонтьев В.В. Топонимический словарь Северо-Востока СССР / В.В. Леонтьев, К.А. Новикова. - Магадан: Кн. изд-во, 1989. - 456 с.

5. Линденау Я.И. Описание народов Сибири (первая половина XVIII века): Историко-этногр. материалы о народах Сибири и Северо-Востока. - Магадан: Кн. изд-во, 1983. - 176 с.

6. Новикова К.А. Лингвистический анализ топонимов северо-восточной Сибири // Вопросы языка и фольклора народностей Севера. - Якутск, 1972. - C. 88-111.

7. Петров А.А. Лексика духовной культуры эвенов. - Л., 1991.

8. Сравнительный словарь тунгусо-маньчжурских языков. Т. І. - Л.: Наука, 1975. -672 c.;

9. Сравнительный словарь тунгусо-маньчжурских языков. Т. ІІ. - Л.: Наука, 1975. -672 c.;

10. Суник О.П. Существительное в тунгусо-маньчжурских языках. - Л.: Наука, 1982. - 247 с.

11. Роббек В.А. Эвенско-русский словарь / В.А. Роббек, М.Е. Роббек. - Новосибирск: Наука, 2005. - 356 с.

12. РЭС - Русско-эвенский словарь / Сост. В.И. Цинциус, Л.Д. Риес. - М.: Изд-во иностранных и национальных словарей, 1952. - 778 с.

\section{References}

1. Danilova, A.A. (1991). Bytovaia leksika evenskogo iazyka. Iakutsk. 
2. Kolesova, M.E. (2006). Tiugosirskii dialekt evenskogo iazyka., 88. Iakutsk: Bichik.

3. Lebedev, V.D. (1978). Iazyk evenov Iakutii., 208. L.: Nauka.

4. Leont'ev, V.V., \& Novikova, K.A. (1989). Toponimicheskii slovar' SeveroVostoka SSSR., 456. Magadan: Kn. izd-vo.

5. Lindenau, Ia.I. (1983). Opisanie narodov Sibiri (pervaia polovina XVIII veka): Istoriko-etnogr. materialy o narodakh Sibiri i Severo-Vostoka., 176. Magadan: Kn. izdvo.

6. Novikova, K.A. (1972). Lingvisticheskii analiz toponimov severo-vostochnoi Sibiri. Voprosy iazyka i fol'klora narodnostei Severa, 88-111. Iakutsk.

7. Petrov, A.A. (1991). Leksika dukhovnoi kul'tury evenov. L.

8. (1975). Sravnitel'nyi slovar' tunguso-man'chzhurskikh iazykov. T. I., 672. L.: Nauka.

9. (1975). Sravnitel'nyi slovar' tunguso-man'chzhurskikh iazykov. T. II., 672. L.: Nauka.

10. Sunik, O.P. (1982). Sushchestvitel'noe v tunguso-man'chzhurskikh iazykakh., 247. L.: Nauka.

11. Robbek, V.A., \& Robbek, M.E. (2005). Evensko-russkii slovar'. Novosibirsk: Nauka.

12. Tsintsius, V.I., \& Ries, L.D. (1952). RES., 778. M.: Izd-vo inostrannykh i natsional'nykh slovarei.

Багдарыын Ньургун Сюлбэ уола - канд. филол. наук, научный сотрудник ФГБУН «Институт гуманитарных исследований и проблем малочисленных народов Севера СО РАН», Россия, Якутск.

Bagdaryyn Nurgun Siulbe uola - candidate of philological sciences, scientific worker at the The Institute for Humanities Research and Indigenous Studies of the North, Russia, Yakutsk. 